\title{
Basic Review of Radiation Biology and Terminology*
}

\author{
Norman E. Bolus, MSPH, MPH, CNMT, FSNMMI-TS \\ Nuclear Medicine Technology Program, University of Alabama at Birmingham, Birmingham, Alabama
}

CE Credit: For CE credit, you can access the test for this article, as well as additional JNMT CE tests, online at https://www.snmmilearningcenter.org. Complete the test online no later than December 2020. Your online test will be scored immediately. You may make 3 attempts to pass the test and must answer $80 \%$ of the questions correctly to receive $1.0 \mathrm{CEH}$ (continuing education hour) credit. SNMMI members will have their CEH credit added to their VOICE transcript automatically; nonmembers will be able to print out a CE certificate upon successfully completing the test. The online test is free to SNMMI members; nonmembers must pay $\$ 15.00$ by credit card when logging onto the website to take the test.

The purpose of this paper is to review basic radiation biology and associated terminology to impart a better understanding of the importance of basic concepts of ionizing radiation interactions with living tissue. As health care workers in a field that utilizes ionizing radiation, nuclear medicine technologists are concerned about the possible acute and chronic effects of occupational radiation exposure. Technologists should have a clear understanding of what they are exposed to and how their safety could be affected. Furthermore, technologists should be knowledgeable about radiation effects so that they can adequately assuage possible patient fears about undergoing a nuclear medicine procedure. After reading this article, the nuclear medicine technologist will be familiar with basic radiation biology concepts; types of interactions of radiation with living tissue, and possible effects from that exposure; theoretic dose-response curves and how they are used in radiation biology; stochastic versus nonstochastic effects of radiation exposure, and what these terms mean in relation to both high- and low-dose radiation exposure; and possible acute and chronic radiation exposure effects.

Key Words: radiation biology; radiation exposure; stochastic radiation effects; nonstochastic radiation effects; acute radiation effects; chronic radiation effects

J Nucl Med Technol 2017; 45:259-264

DOI: 10.2967/jnmt.117.195230

B asic radiation biology concepts include the traditional assumptions of Bergonie and Tribondeau, who stated in 1906 that any cells that are immature, undifferentiated, and actively dividing (e.g., stomach mucosa, basal layer of skin, and stem cells) are more radiosensitive. They respond by exhibiting some effect from radiation exposure that causes cell injury or death. Cells that are mature, differentiated, and not actively dividing (e.g., neurons) are

For correspondence or reprints contact: Norman E. Bolus, University of Alabama at Birmingham, 1705 University Blvd., SHPB, Room 446, Birmingham, AL 35294.

E-mail: bolusn@uab.edu

${ }^{*}$ This basic review article was previously published in Journal of Nuclear Medicine Technology in June 2001.

COPYRIGHT @ 2017 by the Society of Nuclear Medicine and Molecular Imaging. more radioresistant. A cell that is radiosensitive would be more inclined to die after exposure to ionizing radiation than a radioresistant cell (1). Although new terms such as "more or less radioresponsive" are now being used, the basic tenets of their hypothesis hold true for living tissue reactions to ionizing radiation (2). Therefore, cells undergoing active mitosis are more likely to have an effect from ionizing radiation, and stem cells (bone marrow, stomach mucosa, germ layer of the skin) are much more radiosensitive than neurons, which either never replicate or do so very slowly. Experiments in fruit flies and mice have shown that the effects of ionizing radiation can cause mutations in progeny, but these mutations are not specific to radiation. Such mutations are similar to ones that have already been found to occur spontaneously in nature. Furthermore, the experiments showed that the effects of ionizing radiation depend on total dose and exposure rate. A large dose given in a short amount of time is more damaging than the same dose given over a longer period of time (3).

The interaction of radiation with cells is a probability function. Because cellular repair usually takes place, permanent damage will not necessarily result from an interaction of ionizing radiation with living tissue. Energy deposition to a cell occurs very quickly, in some $10^{-18} \mathrm{~s}$, with the energy being deposited in the cell in a random fashion. All interactions happen on a cellular level, which in turn may affect the organ and the entire system. In addition, there is no unique cellular damage associated with radiation. Any damage to a cell due to radiation exposure may also happen due to chemical, thermal, or physical damage. After radiation exposure to a cell, there is a latent period before any observable response. The latent period could be decades for low radiation doses but only minutes or hours for high radiation exposure. These basic generalizations form the foundation on which radiation biology is based (4).

\section{RADIATION INTERACTIONS WITH HUMAN CELLS}

What happens in a cell when ionizing radiation interacts with it? There are really only 2 possibilities: direct interaction or indirect interaction in a cell. 


\section{Direct Interaction}

In direct interaction, a cell's macromolecules (proteins or DNA) are hit by the ionizing radiation, which affects the cell as a whole, either killing the cell or mutating the DNA (2). There are many target and cell survival studies showing that it is harder to permanently destroy or break double-stranded DNA than single-stranded DNA. Although humans have 23 pairs of double-stranded chromosomes, some cells react as if they contain single-stranded, nonpaired chromosomes and are more radiosensitive. Many different types of direct hits can occur, and the type of damage that occurs determines whether the cell can repair itself. Generally, if a direct hit causes a complete break in the DNA or some other permanent damage, the cell dies immediately or will die eventually (5). However, humans have an abundance of cells, and somatic cellular reproduction (mitosis) is always occurring to replace cells that die. Therefore, it is only when this system of replacing cells falters that radiation effects are seen. This occurs at higher doses of radiation.

Actively dividing cells are more radiosensitive than nondividing cells. There are 4 phases of mitosis: $M$ phase, in which cells divide into two; $G_{1}$ phase (gap 1), in which cells prepare for DNA replication; $S$ phase, in which DNA doubles by replication; and $\mathrm{G}_{2}$ phase (gap 2), in which cells prepare for mitosis. Of these, $\mathrm{M}$ phase, in which the chromosomes are condensed and paired, is the most radiosensitive. More DNA is present in one area at this point in the cycle, which is why it is theorized that this is the most radiosensitive time. It is also thought that increased chromatin in cancer cells is why these cells, which have unusually high mitotic rates, are more radiosensitive than normal cells (6).

\section{Indirect Interaction}

The other type of interaction is indirect cellular interaction. Indirect interaction occurs when radiation energy is deposited in the cell and interacts with cellular water rather than with macromolecules within the cell. The reaction that occurs is hydrolysis of the water molecule, resulting in a hydrogen molecule and a hydroxyl (free radical) molecule. If the 2 hydroxyl molecules recombine, they form hydrogen peroxide, which is highly unstable in the cell. This will form a peroxide hydroxyl, which readily combines with some organic compound, which then combines in the cell to form an organic hydrogen peroxide molecule, which is stable. This may result in the loss of an essential enzyme in the cell, which could lead to cell death or a future mutation of the cell (Table 1) (5). Antioxidants, about which there has been much research and publicity, block hydroxyl (free radical) recombination into hydrogen peroxide, preventing stable organic hydrogen peroxide compounds from occurring. This is one way in which the body can defend itself from indirect radiation interactions on a cellular level and is one reason that antioxidants have received so much attention as a cancer prevention agent (7).

\section{CELLULAR INJURY}

There are 3 ways for cellular injury to occur after ionizing radiation exposure: division delay, with dose-
TABLE 1

Hydrolysis of Water (5)

$\mathrm{H}_{2} \mathrm{O}$ (molecule) + ionizing radiation $\rightarrow \mathrm{H}^{+}+\mathrm{OH}^{-}=$(hydroxyl, free radical)

Recombination of:

$\mathrm{H}^{+}+\mathrm{H}^{+} \rightarrow \mathrm{H}^{2}=$ hydrogen gas (not a problem)

$\mathrm{H}^{+}+\mathrm{OH}^{-} \rightarrow \mathrm{H}_{2} \mathrm{O}=$ water (not a problem)

Antioxidants can recombine with the $\mathrm{OH}^{-}$free radical and block hydrogen peroxide formation. If not, then the 2 hydroxyl ions could do the following:

$\mathrm{OH}^{-}+\mathrm{OH}^{-} \rightarrow \mathrm{H}_{2} \mathrm{O}_{2}=$ hydrogen peroxide formation

$\mathrm{H}_{2} \mathrm{O}_{2} \rightarrow \mathrm{H}^{+}+\mathrm{HO}^{2-}=$ unstable peroxide

$\mathrm{HO}^{2-}+$ organic molecule $\rightarrow$ stable organic peroxide

Stable organic peroxide $\rightarrow$ lack of essential enzyme $\rightarrow$ eventual cell death is possible

dependent delay in cell division; reproductive failure, when cells fail to complete mitosis either immediately or after one or more generations; and interphase death, a relatively prompt death caused by the apoptosis mechanism. The last is seen most commonly with lymphocytes, although some cancer cells show apoptosis in response to radiation.

In division delay, mitotic division is delayed but later returns to near normal for unknown reasons. This is seen in doses greater than $0.5 \mathrm{~Gy}$ (50 rad) up to approximately 3 Gy (300 rad). This is the first observable effect from ionizing radiation exposure. At more than 3 Gy (300 rad), the mitotic rate does not recover and the division may never happen, thus killing the cell.

Reproductive failure of a cell is based on the dose. At levels at or below $1.5 \mathrm{~Gy}(150 \mathrm{rad})$, reproductive failure is random and nonlinear. At doses above $1.5 \mathrm{~Gy}$ (150 rad), it is linear and nonrandom. As dose increases, so does reproductive death.

In interphase death, cell death can occur many generations from the initial radiation exposure. It is thought either that this is a natural process of aging cells (apoptosis) or that a critical mechanism of cell replication has been altered. It depends on the type of cell affected and the dose to the cell. Generally, rapidly dividing, undifferentiated cells exhibit interphase death at lower doses than nondividing, differentiated cells.

Any of these types of cellular injury can happen as a result of either direct or indirect cellular interactions with radiation (5).

\section{DOSE-RESPONSE MODELS}

There are many different theoretic types of doseresponse models used to explain the effects of radiation exposure. Different models suggest different possibilities of response to radiation exposure. These range from linearno threshold, which suggests any exposure (even background radiation) is harmful, to the possibility that lowdose radiation exposure is beneficial (radiation hormesis). Three dose-response models used in radiation biology are linear no-threshold, linear threshold, and linear quadratic. 
These dose-response models are used to extrapolate highdose effects (which are known) to the low-dose range (which has not been reliably detected) (Fig. 1).

\section{Linear No-Threshold Model}

For any known carcinogen at any level of exposure (e.g., benzene, asbestos, or high-dose radiation) a linear nothreshold dose-response model is used across all industries. This model states that any radiation exposure, no matter how small, can induce cancer. While this is a possibility, generally no clinical effects are seen below approximately 0.5 Gy (50 rad). The linear no-threshold dose-response model is used for regulatory purposes, whenever a xenobiotic or other carcinogenic agent is known at any dose level (8).

At high doses, or more than 0.5 Gy (50 rad), clinical symptoms of radiation start to appear; at much higher doses, radiation exposure is clearly a known carcinogen, primarily because of its mutagenic effect on cells. The greatest association is with leukemia (9). However, it is difficult to say that any cancer is caused solely by radiation exposure, as cancer may be caused by a combination of factors. Because it is best to err on the side of caution, the "as low as reasonably achievable" (ALARA) principle and the linear nothreshold dose-response model are used.

\section{Linear Threshold Model}

The linear threshold dose-response model consists of a known threshold below which no effects are seen. At the threshold level, effects are noticeable and increase linearly as the dose increases. This is the dose-response model that

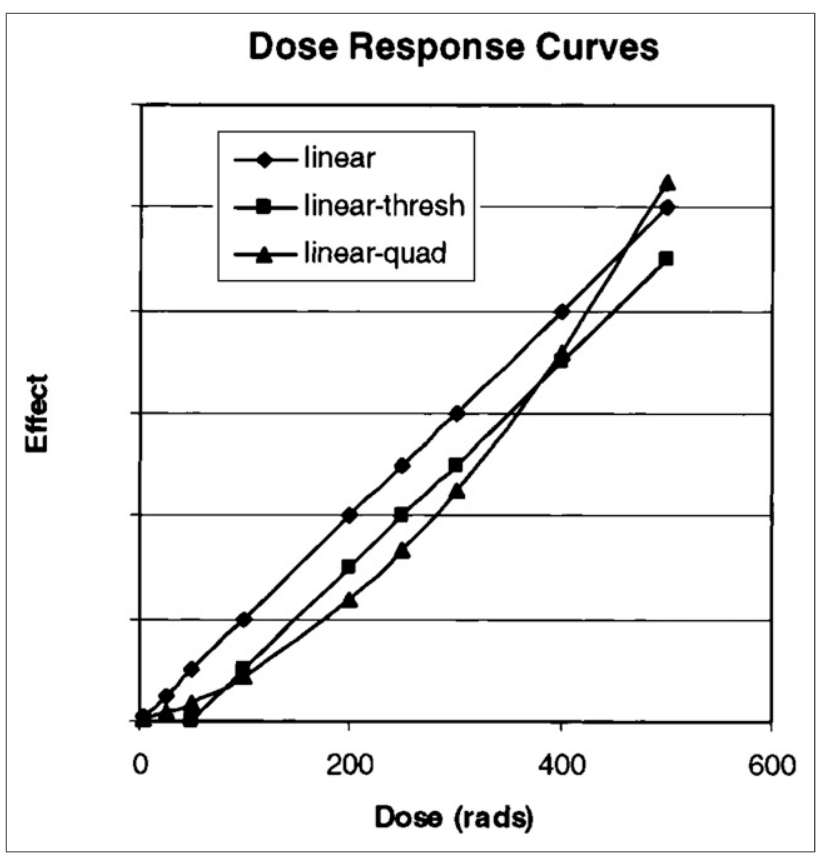

FIGURE 1. This figure shows dose curves that correspond to dose models described in text. Data are measured at high dose levels and then, using curve-fitting techniques, extrapolated to estimate low-dose portion of curve. Low-dose data points shown on these curves are thus estimated, not measured. may make the most sense to use, because it is generally accepted that there are no clinical effects seen from radiation exposure at or below $0.5 \mathrm{~Gy}$ (50 rad). In 1996, the Health Physics Society released the following position statement on low-level radiation (10): "In accordance with current knowledge of radiation health risks, the Health Physics Society recommends against quantitative estimation of health risks below an individual dose of $0.05 \mathrm{~Sv}$ (5 rem) in one year, or a lifetime dose of $0.1 \mathrm{~Sv}$ (10 rem) in addition to background radiation. Risk estimation in this dose range should be strictly qualitative accentuating a range of hypothetical health outcomes with an emphasis on the likely possibility of zero adverse health effects. The current philosophy of radiation protection is based on the assumption that any radiation dose, no matter how small, may result in human health effects, such as cancer and hereditary genetic damage. There is substantial and convincing scientific evidence for health risks at high dose. Below 0.1 Sv (10 rem) (which includes occupational and environmental exposures) risks of health effects are either too small to be observed or are nonexistent." Although this position statement suggests levels 5-fold less for clinical effects, it still indicates that a threshold does exist to a certain degree in radiation exposure. This statement favors a linear threshold dose-response model with a threshold of $0.1 \mathrm{~Sv}$ (10 rem).

\section{Linear Quadratic Model}

The linear quadratic dose-response model is used for overall human response to radiation exposure. Response at low levels of radiation exposure are linear, whereas higher doses are quadratic. There is no threshold in this doseresponse model. In cell survival theories, the linear quadratic dose-response model is used to represent the multiple-target/ single-hit theory. This theory best explains the reaction of human cells to ionizing radiation exposure.

\section{Summary of Dose-Response Models}

It is important to remember that for all dose-response models, the dose makes the poison. Perhaps this was best stated by Paracelsus, who is considered the father of toxicology: "All substances are poisons; there is none which is not a poison. The right dose differentiates a poison from a remedy" (11). Generally, as the dose increases, response increases to a toxic point; in other words, anything in excess can be toxic. Radiation dose-response models vary depending on what is being analyzed. It is important to remember that there is evidence to suggest a possible threshold for radiation exposure that would favor the linear threshold dose-response model. Also, any dose-response model for radiation in the lower levels is extrapolated from what is known at high-dose levels. Thus, any lower-level response from radiation is only theorized, not proven. The only dose-response model accepted by the Nuclear Regulatory Commission is the linear no-threshold dose-response model, which suggests that any radiation exposure can lead to cancer induction. 


\begin{tabular}{|c|c|}
\hline Syndrome & Summary \\
\hline \multirow[t]{8}{*}{ Hematologic } & Dose: Approximately 1-10 Gy (100-1,000 rad) \\
\hline & $\begin{array}{l}\text { Clinical symptoms: General injury of blood-forming cells in bone marrow, which increases with increasing } \\
\text { dose, leading to pancytopenia. This results in bleeding, anemia, hemorrhage, malaise, and severe, } \\
\text { often fatal, infection. }\end{array}$ \\
\hline & Treatment: \\
\hline & 0-1 Gy (0-100 rad)-Reassurance \\
\hline & 1-2 Gy (100-200 rad)_Reassurance and hematologic surveillance \\
\hline & 2-6 Gy (200-600 rad)—Blood transfusion and antibiotics \\
\hline & 6-10 Gy (600-1,000 rad)—Consider bone marrow transplant \\
\hline & $\begin{array}{l}\text { Without treatment, no one has survived a single abrupt dose of } 5 \text { Gy ( } 500 \mathrm{rad} \text { ) or higher. It is possible to } \\
\text { survive the hematologic syndrome with a bone marrow transplant, but at higher doses all subjects } \\
\text { will die from the gastrointestinal syndrome. }\end{array}$ \\
\hline \multirow[t]{7}{*}{ Gastrointestinal } & Dose: Approximately $2-50$ Gy $(200-5,000$ rad) \\
\hline & $\begin{array}{l}\text { Clinical symptoms: Nausea, vomiting, and diarrhea; prolonged diarrhea; dehydration; electrolyte } \\
\text { imbalance; lethargy; anorexia; death above } 10 \mathrm{~Gy}(1,000 \mathrm{rad}) \text { with no treatment. }\end{array}$ \\
\hline & Treatment: \\
\hline & 2-6 Gy (200-600 rad)—Blood transfusion and antibiotics \\
\hline & 6-10 Gy (600-1,000 rad)_Consider bone marrow transplant \\
\hline & $10-50$ Gy $(1,000-5,000$ rad) —Maintenance of electrolyte balance \\
\hline & $\begin{array}{l}\text { At about } 2 \text { Gy ( } 200 \text { rad), classic radiation sickness (nausea, vomiting, and diarrhea) may begin because of } \\
\text { radiation injury to the gastric and intestinal mucosa. }\end{array}$ \\
\hline \multirow[t]{3}{*}{ Central nervous system } & Dose: $>50$ Gy $(>5,000$ rad) \\
\hline & Clinical symptoms: Ataxia, convulsions, lethargy, coma, death \\
\hline & Treatment: Sedatives \\
\hline
\end{tabular}

\section{STOCHASTIC VERSUS NONSTOCHASTIC EFFECTS OF RADIATION EXPOSURE}

Stochastic means random in nature. There is a statistical accounting for all diseases that could be caused by any of several different xenobiotics or carcinogens; any random occurrence of a disease that cannot be attributed solely to radiation is stochastic. As far as cancer is concerned, it is extremely difficult to say whether a particular cancer is attributable to a specific exposure because most cancers have a 20 -y latency period from exposure to manifestation. Therefore, chronic low-dose radiation exposure effects are seen as stochastic. At diagnostic levels, where doses are low, stochastic effects are random and the odds of having any effect are extremely low. A few people may experience an effect from the radiation exposure, but this cannot be predicted. Radiation risks from diagnostic imaging are considered to be stochastic. Also, heredity effects and carcinogenesis are considered to be stochastic (5).

Ionizing radiation at high doses causes certain specific effects. Therefore, at certain doses, certain predictable outcomes can be determined. These are called nonstochastic, or deterministic, effects. These effects are very predictable and range from blood and chromosome aberrations to radiation sickness to certain death, depending on the dose, dose rate, age, immune capacity of an individual, and type of radiation exposure.

For $\gamma$ - and $\mathrm{x}$-ray radiation, exposure measured in grays and sieverts (rads and rems) is equal; however, this is not true of neutron radiation or when the quality factor is greater than 1 for the conversion between rads and rems. Nonstochastic (deterministic) effects include hematologic syndrome (pancytopenia), erythema, gastrointestinal syndrome (radiation sickness), and central nervous system syndrome (Table 2).

One concept used to gauge toxicity is that of the lethal dose to $50 \%$ of the population $\left(\mathrm{LD}_{50}\right)$ exposed to the agent observed at a specific time. The $\mathrm{LD}_{50}$ at $30 \mathrm{~d}\left(\mathrm{LD}_{50 / 30}\right)$ for humans due to ionizing radiation exposure is approximately $2.5-4.5$ Gy (250-450 rad). This estimate for humans varies between different sources and is primarily empiric. Therefore, concrete data are not available. In other organisms, the $\mathrm{LD}_{50 / 30}$ factor has been established through experiments (Table 3) (5).

\section{ACUTE VERSUS CHRONIC EFFECTS}

\section{Acute Radiation Effects}

Acute ionizing radiation exposure is "harmless" at background or diagnostic levels but is nonstochastic and harmful at high-dose levels. At or above approximately $0.5 \mathrm{~Gy}$

TABLE 3

$L_{50 / 30}$ Values for Different Species (5)

\begin{tabular}{lc}
\hline \multicolumn{1}{c}{ Species } & LD $_{50 / 30}$ \\
\hline Cockroach & $50 \mathrm{~Gy}(5,000 \mathrm{rad})$ \\
Rabbit & $8 \mathrm{~Gy}(800 \mathrm{rad})$ \\
Goldfish & $7.5 \mathrm{~Gy}(750 \mathrm{rad})$ \\
Rat & $6 \mathrm{~Gy}(600 \mathrm{rad})$ \\
Mouse & $4.5 \mathrm{~Gy}(450 \mathrm{rad})$ \\
Monkey & $4.5 \mathrm{~Gy}(450 \mathrm{rad})$ \\
Human & $\sim 2.5-4.5 \mathrm{~Gy}(250-450 \mathrm{rad})$ \\
\hline
\end{tabular}


TABLE 4

Summary of Acute Clinical Effects of lonizing Radiation (9)

\begin{tabular}{|c|c|c|c|c|c|c|}
\hline \multirow[b]{3}{*}{ Parameter } & \multicolumn{6}{|c|}{ Radiation exposure range } \\
\hline & \multirow{2}{*}{$\begin{array}{l}\text { Subclinical } \\
\qquad 0-1 \mathrm{~Sv} \\
[0-100 \mathrm{rem}])\end{array}$} & \multicolumn{3}{|c|}{ Therapeutic } & \multicolumn{2}{|c|}{ Lethal } \\
\hline & & 1-2 Sv (100-200 rem) & 2-6 Sv (200-600 rem) & $6-10$ Sv (600-1,000 rem) & $\begin{array}{c}10-50 \mathrm{~Sv} \\
(1,000-5,000 \text { rem })\end{array}$ & $>50 \mathrm{~Sv}(>5,000 \mathrm{rem})$ \\
\hline Treatment required & Reassurance & $\begin{array}{l}\text { Reassurance and } \\
\text { hematologic surveillance }\end{array}$ & $\begin{array}{l}\text { Blood transfusion } \\
\text { and antibiotics }\end{array}$ & $\begin{array}{l}\text { Consider bone } \\
\text { marrow transplant }\end{array}$ & $\begin{array}{l}\text { Maintenance of } \\
\text { electrolyte balance }\end{array}$ & Sedatives \\
\hline Overall treatment plan & None needed & Observation & Effective & Therapy promising & Palliative & Palliative \\
\hline Incidence of vomiting & None & $\begin{array}{l}5 \% \text { at } 1 \mathrm{~Sv}(100 \mathrm{rem}) \\
50 \% \text { at } 2 \mathrm{~Sv}(200 \mathrm{rem})\end{array}$ & $100 \%$ at $3 \mathrm{~Sv}(300 \mathrm{rem})$ & $100 \%$ & $100 \%$ & $100 \%$ \\
\hline $\begin{array}{l}\text { Delay time prior to } \\
\text { vomiting }\end{array}$ & $\mathrm{N} / \mathrm{A}$ & $3 \mathrm{~h}$ & $2 \mathrm{~h}$ & $1 \mathrm{~h}$ & $30 \mathrm{~min}$ & $30 \mathrm{~min}$ \\
\hline Leading organ affected & None & Blood-forming tissue & Blood-forming tissue & Blood-forming tissue & Gastrointestinal tract & Central nervous system \\
\hline Characteristic signs & None & Mild leukopenia & $\begin{array}{l}\text { Severe leukopenia; } \\
\text { hemorrhage; hair loss } \\
\text { above } 3 \mathrm{~Sv} \text { (300 rem) }\end{array}$ & $\begin{array}{l}\text { Severe leukopenia; } \\
\text { infections; erythema }\end{array}$ & $\begin{array}{l}\text { Diarrhea; fever; } \\
\text { electrolyte } \\
\text { imbalance }\end{array}$ & $\begin{array}{l}\text { Convulsions; tremor; } \\
\text { ataxia; lethargy }\end{array}$ \\
\hline $\begin{array}{l}\text { Critical period } \\
\text { after exposure }\end{array}$ & $\mathrm{N} / \mathrm{A}$ & N/A & $4-6$ wk & $4-6$ wk & $5-14 d$ & $1-48 \mathrm{~h}$ \\
\hline Prognosis & Excellent & Excellent & Good & Guarded & Hopeless & Hopeless \\
\hline Incidence of death & None & None & $0 \%-80 \%$ & $80 \%-100 \%$ & $90 \%-100 \%$ & $90 \%-100 \%$ \\
\hline Cause of death & $\mathrm{N} / \mathrm{A}$ & $\mathrm{N} / \mathrm{A}$ & Hemorrhage and infection & Hemorrhage and infection & Circulatory collapse & $\begin{array}{l}\text { Respiratory failure and } \\
\text { brain edema }\end{array}$ \\
\hline
\end{tabular}

TABLE 5

Staging of Acute Radiation Syndromes (5)

\begin{tabular}{ll}
\hline \multicolumn{1}{c}{ Phase } & Description \\
\hline Prodromal ("running before") & $\begin{array}{c}\text { Signs and symptoms include nausea, vomiting, and diarrhea; hair loss above } 3 \text { Gy (300 rad); } \\
\text { skin erythema above } 6 \text { Gy (600 rad) }\end{array}$ \\
$\begin{array}{ll}\text { Period of no signs or symptoms } \\
\text { Latent }\end{array}$ \\
$\begin{array}{l}\text { Nausea, vomiting, and diarrhea return; hematologic syndrome; gastrointestinal syndrome; } \\
\text { central nervous system syndrome; signs and symptoms return to prodromal levels or worse } \\
\text { If good treatment is provided and the affected individual received less than a 10-Gy (1,000-rad) } \\
\text { dose, recovery is possible after the manifest phase }\end{array}$ \\
\hline
\end{tabular}

(50 rad), acute effects are predictable and follow a linear path. Some chromosome aberrations may be seen under a microscope at or below $0.5 \mathrm{~Gy}(50 \mathrm{rad})$, but no clinical symptoms have been found to manifest from this observation. However, this can be used as a bioassay technique years after an acute exposure. Table 4 shows the generally accepted acute effects and symptoms these dose ranges can be expected to manifest (8). There are sequelae of acute ionizing radiation exposure from which certain welldefined syndromes can be expected (Table 5) (5).

In radiation therapy, acute nonstochastic effects of radiation exposure include radiation fibrosis in the lung when normal lung tissue is exposed. Other tissues that show effects are the kidney, brain, and spinal cord. Because tissue injury is known to occur if a certain threshold is exceeded, there are well-established guidelines in radiotherapy to avoid exceeding a specific dose (12).

\section{Chronic Radiation Effects}

Chronic effects of ionizing radiation exposure are primarily stochastic. The chief concern is possible cancer induction. However, noncancerous effects are possible, such as cataract formation in the eye. This would be a possible stochastic chronic effect, with a probability that increases with increasing dose. Radiation doses of 500-800 R directed at the lens of the eye can cause formation of cataracts. At lower doses, damage is similar to senile cataracts but is less severe. Another possible chronic stochastic effect is shortening of the life span. Although there is no conclusive evidence of such, it is theorized in some literature (8).

As a stochastic effect, leukemia has been associated with chronic radiation exposure at doses as low as $50-100 \mathrm{cGy}$ (50-100 rad). Between 100 and 500 cGy (100-500 rad), there is a linear correlation between dose and leukemia

\section{TABLE 6}

Average Annual Effective Dose Equivalent to a Member of the U.S. Population $(14,16)$

\begin{tabular}{lc}
\hline \multicolumn{1}{c}{ Source } & Effective/whole-body dose \\
\hline $\begin{array}{l}\text { Average annual dose to } \\
\text { U.S. population from all } \\
\text { sources }\end{array}$ & $6.2 \mathrm{mSv}(0.62 \mathrm{rem})$ \\
Radon \& thoron & $2.28 \mathrm{mSv}(0.228 \mathrm{rem})$ \\
$\begin{array}{l}\text { Conventional radiography \& } \\
\text { fluoroscopy }\end{array}$ & $0.33 \mathrm{mSv}(0.033 \mathrm{rem})$ \\
\hline Computed tomography & $1.47 \mathrm{mSv}(0.147 \mathrm{rem})$ \\
Nuclear medicine & $0.77 \mathrm{mSv}(0.077 \mathrm{rem})$ \\
Consumer products & $0.13 \mathrm{mSv}(0.013 \mathrm{rem})$ \\
Cosmic radiation & $0.33 \mathrm{mSv}(0.033 \mathrm{rem})$ \\
\hline Terrestrial radiation & $0.21 \mathrm{mSv}(0.021 \mathrm{rem})$ \\
\hline
\end{tabular}


TABLE 7

Whole-Body Patient Doses from Nuclear Medicine Procedures (15)

\begin{tabular}{lc}
\hline Radiopharmaceutical & cGy/mCi (rad/mCi) \\
\hline${ }^{67}$ Ga-citrate & 0.26 \\
${ }^{201}$ TI-chloride & 0.21 \\
${ }^{18}$ F-FDG & 0.04 \\
123--iodide & 0.03 \\
99mTc-sulfur colloid & 0.019 \\
\hline 99mTc-MIBI & 0.017 \\
99mTc-DTPA & 0.016 \\
99mTc-DISIDA & 0.016 \\
99mTc-MAA & 0.015 \\
99mTc-HMPAO & 0.013 \\
99mTc-pertechnetate & 0.011 \\
99mTc-MDP & 0.007 \\
99mTc-MAG3 & 0.007 \\
\hline
\end{tabular}

incidence. Data suggest that the incidence of leukemia increases at a rate of 1-2 cases per million per year per centigray ( $1 \mathrm{rad})$ as a result of exposure. There is an average latency period of $14 \mathrm{y}$ from exposure to onset of disease. Higher doses of ionizing radiation have also been associated with thyroid, bone, lung, and various other cancers (8).

Interestingly, there is no conclusive evidence that chronic low-dose radiation exposure causes any long-term ill health effects in workers in the medical field (13). Furthermore, there is no evidence to suggest that regular background amounts of radiation exposure cause any long-term effects. Table 6 indicates the average annual effective dose equivalent of ionizing radiation to a member of the U.S. population. Relative to the amounts of radiation that elicit a known response, these levels are low. Likewise, the amounts of whole-body doses of radiation that patients receive from various nuclear medicine procedures are low, as seen in Table 7. Technologists should monitor their radiation dosimetry reports to track their own occupational exposure. However, technologists who stay below the accepted occupational dose limits should not expect to experience any ill effects.

TABLE 8

Occupational Dose Limits (Total Effective Dose Equivalent Limits) (15)

\begin{tabular}{lc}
\hline \multicolumn{1}{c}{ Region of body } & Annual limit in cSv (rem) \\
\hline Whole body & 5 \\
Extremities (hand, forearm) & 50 \\
Skin & 50 \\
Any internal organ & 50 \\
Lens of the eye & 15 \\
\hline
\end{tabular}

Cumulative lifetime dose $=1 \mathrm{cSv}(\mathrm{rem}) \times$ age. Fetal dose $=0.5$ $\mathrm{cSv}(\mathrm{rem}) / 9 \mathrm{mo}$, not to exceed $0.05 \mathrm{cSv}(\mathrm{rem}) / \mathrm{mo}$. General public in nonrestricted areas $=0.002 \mathrm{cSv}(\mathrm{rem}) / \mathrm{h}$ or $0.1 \mathrm{cSv}(\mathrm{rem}) / \mathrm{y}$.

\section{CONCLUSION}

This brief synopsis of radiation biology is intended as a review of terminology and concepts. Unfortunately, conclusive information is elusive at the low-dose levels of radiation exposure that technologists encounter. Stochastic low-dose radiation exposure effects are only theorized from extrapolating data from known responses of high-dose radiation exposure. High-dose radiation effects are well established and follow nonstochastic (deterministic) responses. In the safety industry, protection of personnel working with known carcinogens is paramount. The radiation industry is no different from other industries that have threshold limit values and biologic exposure indices for worker exposure. These allowed limits offer a guideline for acceptable exposure, below which no ill effects are expected. In the radiation industry, these are known as total effective dose equivalents (Table 8).

Radiation biology is a diverse field that covers many areas of knowledge, including cell biology, chemistry, radiation physics, human physiology, radiation safety, epidemiology, biostatistics, and toxicology. Information about this topic continues to evolve as more knowledge is obtained about ionizing radiation interactions with cells. It can be confusing to delve into radiation biology without understanding the basic concepts outlined in this article. Be aware that this overview barely begins to discuss all of the information available about radiation biology.

\section{REFERENCES}

1. Bergonie J, Tribondeau L. De quelques resultats de la radiotherapie et essai de fixation dune technique rationelle. CR Acad Sci. 1906;143:983.

2. Nias AHW. An Introduction to Radiobiology. 2nd ed. Chichester, England: Wiley; $1998 ; 4$.

3. Muller HJ. Artificial transmutation of the gene. Science. 1927;66:84.

4. Seeram E. Radiation Protection. Philadelphia, PA: Lippincott; 1997:74-92.

5. Dowd SB, Tilson ER. Practical Radiation Protection and Applied Radiobiology. 2nd ed. Philadelphia, PA: Saunders; 1999:118-120.

6. Chapman JD, Stobbe CC, Gales T, et al. Condensed chromatin and cell inactivation by single hit kinetics. Radiat Res. 1999;151:433-41.

7. Raloff J. Panel ups RDAs for some antioxidants. Science News. April 15, 2000:244.

8. Implementation of the Principle of as Low as Reasonably Achievable (ALARA) for Medical and Dental Personnel. Bethesda, MD: National Council on Radiation Protection and Measurements; 1990.

9. Ladou J. Occupational Medicine. Norwalk, CT: Appleton \& Lange; 1990:197-198.

10. Mossman KL, Goldman M, Masse F, et al. Radiation risk in perspective: Health Physics Society position statement. Idaho State University Department of Physics and Health Physics website. http://www.physics.isu.edu/radinf/hprisk.htm. Published March 1996. Accessed March 14, 2017.

11. Klaassen CD, ed. Casarett \& Doull's Toxicology: The Basic Science of Poisons. New York, NY: McGraw-Hill; 1996:4.

12. Selman J. Elements of Radiobiology. Springfield, IL: Charles C. Thomas;1983:98.

13. Bolus NE. A brief literature summary on the occupational hazard of chronic lowdose radiation exposure and suggested requirements for further study. RSO Magazine. July/August 1997:27-30.

14. Radiation Exposure of the US Population from Consumer Products and Miscellaneous Sources. Bethesda, MD: National Council on Radiation Protection and Measurements; 1987.

15. Lombardi MH. Radiation Safety in Nuclear Medicine. Boca Raton, FL: CRC Press; 1999:137.

16. Ionizing Radiation Exposure of the Population of the United States. Bethesda, MD: National Council on Radiation Protection and Measurements; 2009. Report 160 . 